\title{
THE BLUE ALIEN IN KOI MIL GAYA FILM: POPULAR LITERATURE
}

\author{
Luluk Hanikmah \\ Department of English Teaching, IKIP PGRI Madiun, Indonesia \\ Lulunugraha5@gmail.com
}

\begin{abstract}
The purpose of this research is to describe the blue alien as the phenomenon Alien's representation in science fiction of Bollywood and Bollywood's action in bringing outer space alien to Indian culture that is represented in Koi Mil Gaya film. This research uses qualitative research. The researcher needs popular literature by Ida Rochani Adi to get what the author is willing to share her readers. It is also a way to the researcher to investigate why the author choose alien as the new character, and is there popular culture inside the character evidences the effects and goals of the author in creating a story. The analysis reveals that the alien's representation of Bollywood's science fiction, and Bollywood's action in bringing outer space alien to India culture. The conclusion shows there are similar formula in each Bollywood science fiction in alien's representation and Bollywood action in bringing outer space alien to India culture is influenced by 3 factors, there are: Hollywood influence, Ancient India influence, and popular news in India. The researcher uses the symbol to analyze the blue alien as the representation of Lord Krishna. It is Hindu mythology. Hindu mythology is popular culture in India belief. It is appropriate with the researcher's assumption that the blue alien has correlation with India culture. In conclusion, the alien which has blue skin is the appearance of Lord Krishna.
\end{abstract}

Keyterms: Popular Literature, India Culture, Alien's Representation.

\section{INTRODUCTION}

Koi Mil Gaya is one of science fiction film made in 2003 directed by Rakesh Roshan. This film has received many awards. Koi Mil Gaya film was the most successful Bollywood film in 2003 is chosen by the researcher to be analyzed. This novel tells about tells about an alien (Jadoo) that make it becomes the first science fiction figure as the representation of God in Bollywood. The main character Jadoo is an alien who has a physical form mixture between humans and animals. He also has blue color in his body. Jadoo the first alien figure created by Bollywood in their filmmaking. This problem makes the researcher more interests to analyze the alien figure that has correlation with India culture

The researcher will analyze a film entitled Koi Mil Gaya by Rakesh Roshan in 2003 by using Popular Literature by Ida Rochani Adi in 2011. Adi (2011: 132) interdisciplinary research in relation with popular fiction, the importance of looking at the elements underlying the culture of popular fiction. It is writes that as a domain within formula, cultural studies, semiotic that literature produced by culture developed in response to alien figure but also theoretical framework that seeks to understand the blue alien has correlation to India culture. It means that popular literature is the interpretation of literature which is influenced by culture inside of societies.

English Teaching Journal: A journal of English Literature, Linguistics, and Education 10| 
English Teaching Journal, Vol. 4 No. 1, Juni 2016

ISSN: 2338-2678

Based on the explanation above, the researcher is curious about the blue alien. The researcher wants to know culture inside of Koi Mil Gaya film because the film would make people eager to watch it. Besides, the researcher wants to investigate why the author choose alien as the new character, and is there popular culture inside the character. Why is the intention of the author and how representation of alien could say something are other problems in this popular literature studies.

\section{METHOD}

The researcher uses qualitative research because the research analyzes the blue alien as phenomena in this study. In qualitative research, the researcher begins the study by getting data from the primary and secondary data J. Hox and R. Boeije (2005: 593) focusing on Koi Mil Gaya film and resources such as journal, article, or web related with the analysis of the blue alien as study of popular literature. This research takes documentation as technique of collecting data because this research is qualitative research Ary et al (2010: 442). The researcher collects the data through watching the film, browsing the related data, doing research, reviewing related studies, and using theory of popular literature to interpret the phenomena about the blue alien represented in Koi Mil Gaya film. This study uses content analysis because the data form of text or literary document by Ary et al (2010: 457).

\section{DISCUSSION}

The discussion will start identifying the alien's Alien's representation in science fiction of Bollywood, here the researcher uses formula to identified it, and Bollywood's action in bringing outer space alien to Indian culture, here the researcher uses interdisciplinary approach to identified it. The necessary popular literature theory by Ida Rochani Adi as data are as follows. The researcher uses formula to solve the problem statements 1 that is formula. It is to collecting the data of each Bollywood's science fiction that has a similar formula. The researcher found the data from list of Bollywood's science fiction film.

Table 1.1. Data of Science Fiction in Bollywood Film.

\begin{tabular}{clcc} 
No & Title & Year & Alien Character \\
\hline 1 & Koi Mil Gaya & 2003 & Jadoo \\
\hline 2 & Joker & 2012 & Alien \\
\hline 3 & PK & 2014 & PK \\
\hline
\end{tabular}

11 | The Blue Alien In Koi Mil Gaya Film: Popular Literature 
Source: Uniqueaby. (2014). http://www.imdb.com/list/ls058906210/

Film on this table are based on the release time. The film that have been chooses by the researcher is the films liked by many people. There are many of Bollywood film that uses science fiction genre, but in this thesis, the researcher wants to take Bollywood film genre focus on Aliens. Films about alien science fiction genre above starting from the 2003 film entitled Koi Mil Gaya until film in 2014 entitled $P K$.

Koi Mil Gaya is the primary data of this study, while the genre approach is needed to support the film. To analyze the genre needed a formula. The formula of Koi Mil Gaya needs the formula of other films that provide evidence about alien. The function is to see the development of the formula

\section{A. Alien of Science Fiction Genre: The Formulaic Analysis}

The researcher wants to focus on formula of the science fiction genre that involves alien (Jadoo's character). According to Adi (2011: 209) "The research that examines the genre elements of the formula are generally not done by looking at the quality, but its effectiveness in attracting readers or viewers that research conducted extrinsic." Extrinsic itself refer to the culture. So, in investigate a culture, it must be uses the extrinsic approach. So, the researcher uses formula to analyze alien of Koi Mil Gaya film in the below.

\section{Alien Comes in Distance Place}

The first formula is alien comes in distance place. The researcher finds the similar formula in each Bollywood's science fiction film. In Koi Mil Gaya film, the alien (Jadoo) comes to the earth in the jungle of Kasauli. Jungle is the one of distance place. Figure 2.2. at 1:23:39 - 1:24:10 illustrates that Aliens landed in the woods. Aliens is coming out of their spacecraft. They walk the jungle.

Some of the Alien film uses science fiction genre in Bollywood industry film has similarities and differences in filmmaking. The researcher explain the differences and similarities in Koi Mil Gaya film with another alien film. The similarities between Koi Mil Gaya film and the other films are: first, in $P K$ film, the Alien comes with spacecraft, in $K o i$ Mil Gaya film, the alien also comes with spacecraft. Second, in Joker film, the body shape of alien is like an animal. The differences are: first, In Koi Mil Gaya and PK film, the alien comes by using spacecraft, but in Joker film, there are no explanation about the coming of the alien. Second, in Koi Mil Gaya and Joker film, the alien uses animal body's shape, but in 
English Teaching Journal, Vol. 4 No. 1, Juni 2016

ISSN: 2338-2678

$P K$ film, the alien has changes to be like a human. Third, in Koi Mil Gaya and Joker film, the alien arrives in the jungle, but in $P K$ film, the alien arrives in the desert.

\section{Alien is Human's Friend}

The second formula is alien is Human's friend. The researcher finds the similar formula in each Bollywood's science fiction film. In Koi Mil Gaya film, after the alien (Jadoo) comes to the earth, Jadoo has lost contact with the other aliens. So, it make Jadoo stays in the Jungle. Then, Jadoo meets Rohit when Rohit helped him from dog. It make Jadoo to be Rohit's friend finally.

Figure 2.3.: 1:20:16 - 1:21:20 shows that a human communicate with the alien by shaking hands. The image above is proof that Rohit (man) asked the Alien to get acquainted with how to shake hands and say "will you be my friend". And the Alien also meets the demand Rohit and took her hands to shake hands. It shows that the aliens understand the words of Rohit. It is also intended to communicate.

In the Bollywood films that uses the alien as an object also tells about the conversation between alien with human. In the Joker film has similarities with Koi Mil Gaya film that tells human can communicate with alien. The $P K$ film also tells that the alien can communicate directly with human. This is the proof of this study that the imagination of the author is people are able to communicate with the aliens directly.

\section{Alien Use a Power / Magic}

The third formula is alien use a power/magic. The researcher finds the similar formula in each Bollywood's science fiction film. In Koi Mil Gaya film, Jadoo has a magical power to help Rohit. Not only help Rohit but also Rohit's friends.

Figure 2.7. at 1:21:48 shows that Jadoo uses its power (magic). Jadoo uses its power to treat the Rohit's affected hand by the claws of wild dogs when he wants to help Jadoo. Finally the claw wounds disappear instantly when the golden light that comes out of the hands of the alien touching hands Rohit. It is like magic.

In the other alien film of Bollywood, $P K$ is one of film that alien used his power to absorb the language trough the women's hand. In Joker film, the alien uses his power to protect himself from the people.

\section{Response of Societies}

The fourth formula is response of societies. The researcher finds the similar formula in each Bollywood's science fiction film. In Koi Mil Gaya film, the alien has

\section{3 | The Blue Alien In Koi Mil Gaya Film: Popular Literature}


troubled situation. The response of societies is Jadoo has caught the police, because the alien will be alien's research object for the government.

Figure 2.12.: at 2:28:00 - 2:30:00 shows that Rohit embraces Jadoo (alien) to protect him from the police. Rohit also struggles the police officer. It is because Jadoo will be caught by the police officer.

In the other Bollywood film that tells about alien, it has different action of societies. In $P K$, the response of societies is accepting $P K$ in their life. It is because the alien's (PK) body like a human being. In Joker film, the response of societies is Agastya hidden the alien from the society, because the society afraid if the alien will against them.

\section{Alien return to spacecraft}

The five formula is alien return to spacecraft. The researcher finds the similar formula in each Bollywood's science fiction film. In Koi Mil Gaya film. In the ending of Koi Mil Gaya film, Jadoo must return to Jadoo's planet. It is because the existence of alien has been known by many people. So, the best way is Jadoo return to Jadoo's planet.

Figure 2.13. at 2:38:35 - 2:39:20 illustrates that Rohit accompany Jadoo to entry in his spacecraft because his existence have been known by police. If Jadoo does not return to his planet, he will be arrested by police.

The other alien film of Bollywood also has similarities scene like in Koi Mil Gaya film. It is $P K$ film. In the ending $P K$, the alien called PK also go back into his spacecraft to go their planet. In Joker film, the end of the film has similarities with the ending of Koi Mil Gaya film, the alien return to Alien's planet.

\section{B. Bringing outer space to India culture}

The author of Koi Mil Gaya presents story about an alien arrival in India. In this part, the researcher would like to discuss the relationship of alien figure with the culture of India. It is the assumption of the researcher. According to Adi "popular fiction is categories of mass culture (2011: 133)". Thus, if a researcher analyzes the popular fiction, it is also about analyzing the culture that influences popular fiction. There are 3 factor that influence Bollywood bring outer space in their filmmaking.

\section{a. The Hollywood Influence}

The researcher have found some factors of bringing alien in Koi Mil Gaya film. The first factor is that Bollywood industry have been cooperated with Hollywood in their filmmaking.

"In the same vein, Alessio and Langer in the article titled Nationalism and Postcolonialism in Indian Science Fiction: Bollywood's Koi....Mil Gaya, demonstrate how 
Bollywood has borrowed heavily from Hollywood, another moment of cultural imperialism. This is so because whatever elements are borrowed from Hollywood embedded in them are American or Western values, beliefs, knowledge, etc. (J. Ireri and Parameswaran, 2010: 15)

It affects Bollywood filmmaking. So, Bollywood is very inspired by Hollywood films. Therefore, Bollywood used Alien in Koi Mil Gaya film to interest the audience. Koi Mil Gaya film is inspired by E.T (Extratrrestrial) film produced by Steven Spielberg. According to Basu (2011: 567) “Koi Mil Gaya copies a spectacular basketball sequence from The Absent Minded Professor, but overall it has greater similarities to Steven Spielberg's E.T.: The Extra-Terrestrial (1982)." It means that Bollywood inspired by Hollywood film.

\section{b. The Ancient Indian Influence}

The second factor tells about ancient India. India has many ancient temple, ancient statue, ancient scripture, etc. The researcher is interested in ancient scripture in India. There is relationship between alien in Koi Mil Gaya film with ancient India.

In the film, the alien arrived in the forest by using spacecraft. The spacecraft itself is usually called as UFO (Unidentified Flying Object). India ancient scripture also has flying object called vimana. According to Pattanaik (2004: 174) "the Ramayana talks about a flying chariot calls pushpaka vimana. To many the account of this chariot is not poetic imagination but historical evidence that airplanes existed in Vedic times." So, in ancient times, the flying source exists.
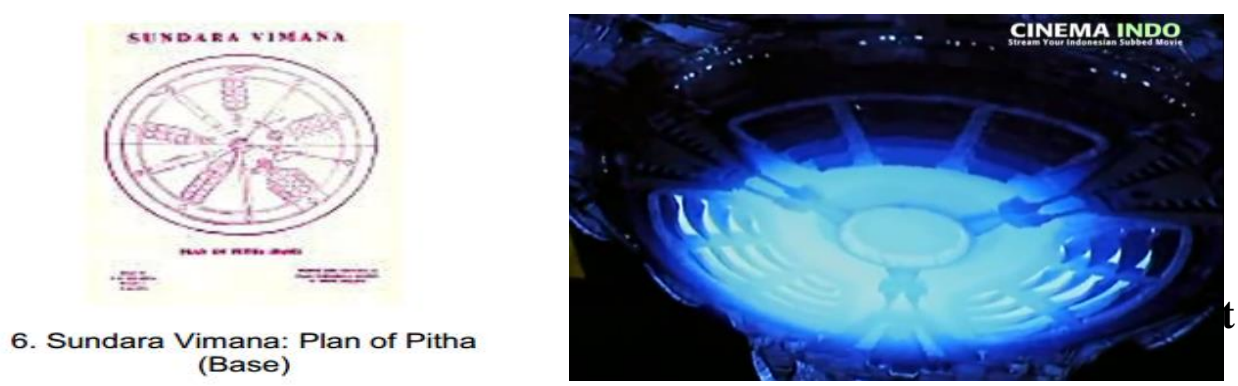

Based on the investigation above, there are similarity in shape (base) of flying machine in India (vimana) and flying object in Koi Mil Gaya film. It can prove that alien in Koi Mil Gaya has correlation with ancient India. So, the investigation of the researcher is correct if Bollywood inspired with ancient India.

\section{c. The India Popular News Influence}

\section{5 | The Blue Alien In Koi Mil Gaya Film: Popular Literature}


The researcher finds the data for the third factor is taken from popular news in India. According to Gans in Adi "cultural product cannot exist far from the society who create and use it (2011: 132)." Thus, the researcher seek the factor of influencing the alien in society

Source: taken in 01:11:60

Reported: A similar UFO sighting was reported in Banglore in May, 2001.

The data above is the news in Koi Mil Gaya film that is reported after the coming of UFO. The researcher finds the reason of the author why he chooses alien in Koi Mil Gaya film. It is because in 2001, there was news reported UFO sighting in Banglore India. Vike (2012) states "if he saw the UFO like a big Airplane use triangular shape with 3 lights on each end. Thus, the researcher concludes that film making of Koi Mil Gaya is inspired by the popular news in India.

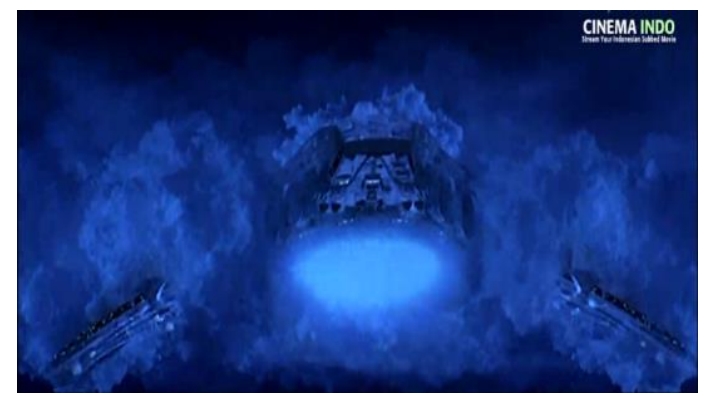

Figure.3.5.TheBody of Flying Object

Based on the picture above, the shape of spacecraft of alien in Koi Mil Gaya film is triangular. It is appropriate with Vike's statements. So, the author inspired by Vike that uses the alien in the film because it is a familiar news when it was reported in 2001. It proves that the popular news influences Koi Mil Gaya film.

\section{The symbol analysis}

The researcher uses semiotic theory to analyze this study. The researcher explains about Bollywood action in filmmaking their film industry. So, the researcher wants to analyze the symbol of alien representation of Krishna, because Bollywood shows the symbol in their filmmaking. The researcher has found the data to solve the second problem statement in this study such as mythology of Lord Krishna and Alien which connect to Koi Mil Gaya film as the primary data. Koi Mil Gaya film has Alien as the object to interest the audience. Koi Mil Gaya film has been choosen because it has science fiction genre. According to Adi (2011: 210) "Involvement of society is very important in creation of popular fiction formula because the culture which underlies inception of popular fiction that try to fulfill mass necessity." So, the film industry always insert the culture of society in their filmmaking to 
fulfill necessity of society or audience. It is like Bollywood industry film that every film exhibits the culture of element to the audience. One of them is about religiousity. The religiousity of India is always showed in Bollywood films, such as the myth of Lord (Dewa) and the rituals. It can be interesting to the audience who like all of Bollywood films. It is the reason of Bollywood industry film of using religiousity to increase sales of their filmmaking because the myth of Lord (Dewa) to be in demand by the India society.

\section{The first symbol : the mark in forehead of Jadoo and Krishna}

In the first symbol, the researcher finds the mark on Jadoo's forehead. It is like the word "U" between his eyebrows. In Hinduism, the mark " $U$ " in forehead is called as Tilak.
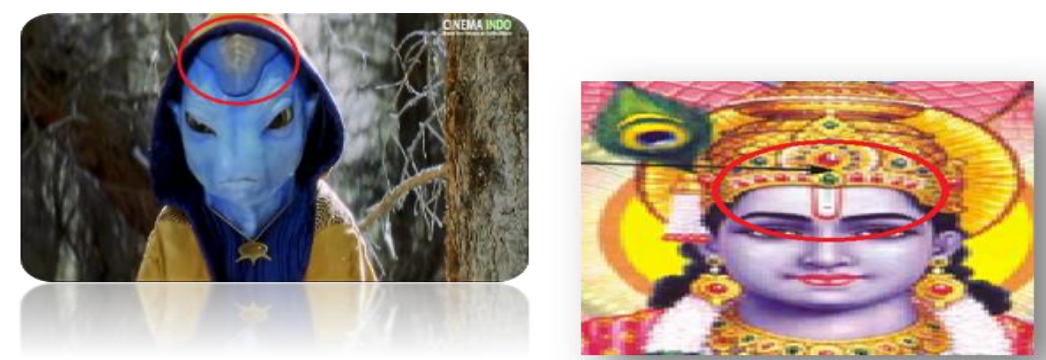

Based on the picture above, the researcher conclude that the alien is representation of Lord Krishna. It is because they have similarities in their forehead symbol. So, the first symbol is proven from investigation by the researcher.

The second symbol: the color of alien

The second symbol is the symbol of color. There are two colors that show the symbols of alien representation of Lord Krishna.
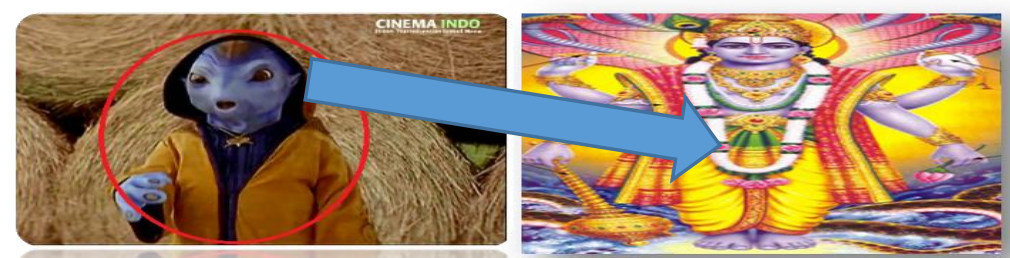

The researcher finds the yellow color on the clothes and in head of the alien. According to Verma (2014: 2) "YELLOW is the color of knowledge and learning. It symbolizes happiness, peace, meditation, competence and mental development." It means that the yellow color has the meaning in Hinduism. So, the researcher conclude that the alien is representation of Lord Krishna because there are similarities portrayal of dresses and alien's forehead. In Koi Mil Gaya film, the alien also wear dresses with the yellow color. In alien's forehead also use yellow color as his magical power that helps Rohit to be a smart man.

The third symbol : uses sunlight as the energy of Alien

\section{7 | The Blue Alien In Koi Mil Gaya Film: Popular Literature}


In this third symbol, the researcher wants to investigate the symbol of Alien who showing sign that the Alien is representation of Lord Krishna. The Alien uses sunlight as the power of his energy or power.

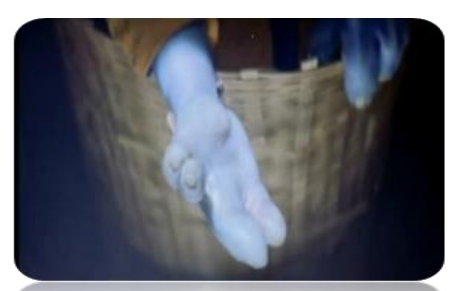

According to Prabhupada (2002: 36

"One has to understand Your

appearance with great intelligence

because the material energy is also

emanating from You. You are the

original source of the material energy,

just as the sun is the source of the sunshine."

The researcher conclude that the Alien is representation of Lord Krishna, because both of them uses sun as the power of their energy. According to Prabhupada (2002: 36) "One has to understand Your appearance with great intelligence because the material energy is also emanating from You. You are the original source of the material energy, just as the sun is the source of the sunshine." Yours is Lord Krishna. It means that Lord Krishna also uses sunshine as his energy. Based on the symbols above, the researcher conclude that there is connection between Alien and Lord Krishna using semioticsof symbols as approach of popular literature theory.

\section{CONCLUSION}

The study of Koi Mil Gaya film by Rakesh Roshan discusses about the Blue alien invitation in India. The researcher analyzes the formula of the blue alien in each Bollywood film that has the same formula about alien invitation and Bollywood do in bringing outer space to India as the problems of study. In Koi Mil Gaya film, the blue alien has the similar formula with the other alien films in Bollywood. It is also make development formula changes. The alien's body in Koi Mil Gaya and Joker film has similar shapes like an animal, but in $P K$ film, the alien's body like a human. there is connection between the blue alien and India culture. The researcher seeks through cultural perspective and semiotic to prove it. The researcher finds the popular culture in India is Hindu mythology. Hindu mythology always tells about Gods and Goddesses in India's belief. Koi Mil Gaya film also has the culture behind the film. In conclusion, the alien with blue skin has some similar appearance as Lord Krishna.

\section{ACKNOWLEDGEMENTS}

The researcher would like to gratitude to the following persons: Mr. Jatno and Mr. Abdul Rachman Safi'in as her fathers, Mrs. Sulip Yanik as her mother, and her friends. Those are supporting me during the process. 


\section{REFERENCES}

Adi, I. R. (2011). Fiksi Populer Teori dan Metode Kajian. Jogjakarta: Pustaka Pelajar.

Aggarwal, B. Significance of Hindu Deities (Symbolism). Hindu University of America. 113 N. Econlockhatchee Trail Orlando, FL 32825 407-275-0013 www.hua.edu, staff@hua.edu407-275-0013.

Basu, A. (2011). The Eternal Return and Overcoming 'Cape Fear': Science, Sensation, Superman and Hindu Nationalism in Recent Hindi Cinema, South Asian History and Culture. Department of English and Unit of Cinema Studies, University of Illinois at Urbhana-Champaign, Urbana, IL, USA, Vol.2, No. 4, October 2011, 557-571.

Bharadwaaja, M. (1973). Vymaanika - Shaastra Aeronautics. India: Printed at Coronation Press, Mysore-4.

Ganti, T. (2004). Bollywood, A Guidebook to Popular Hindi Cinema. New York and London: Routledge.

Held, D.; McGrew, A.; Goldbaltt, D. \&Perraton, J. (1999). Contents and Introduction in Global Transformations: Politics, Economics and Culture. Stanford: Stanford University Press, 1-31.

Hox, J. J. \&Boeije, H. R. (2005) Data Collection, Primary vs. Secondary. Encyclopedia of Social Measurement, Inc. All Right Reserved, Vol. 1 (2005).

Ireri, J. K. (2010). Globalization: A Critical Literature Review of Bollywood. Indiana University.

Khotari, C. R. (2004). Research Methodology, Methods and Techniques. Jaipur (India): New Age International Publishers.

Lewis, J. R. (2000). UFOs and Popular Culture: an Encyclopedia of Contemporary Myth. United States of America.

Marez, C. (2004). Aliens and Indians: Science Fiction, Prophetic Photography and NearFuture Visions. Journal of Visual Culture: SAGE Publications (London, Thousand Oaks, CA and New Delhi) Vol 3(3): 336-352.

Moti, K. G \&Wimal, D. (2009) Popular Culture in Globalized India. New York: Routledge.

Pattanaik, D. (2003). Indian Mythology: Tales, Symbols, and Ritual. Inc. Bibliographical References and Index.

Prabhupada, A. C. B. S. (2002). Krishna the Supreme Personality of Godhead. The Bhaktivedanta Book Trust International, Inc. All rights Reserved.

Uniqueaby. (2014). http://www.imdb.com/list/ls058906210/. 
Väätänen, P. (2009). Sun Ra: Myth, Science, and Science Fiction. Fafnir - Nordic Journal of Science Fiction andFantasy Research, Vol. 1, iss 4, pages 39-46.

Verma, Dr. R. (2014). Social Significance of Color.Govt. Girl College Neemuch (M.P.): International Journal of Research - Granthaalayah, ISSN. 2350-0530.

Vike, B. (2012). UFO Sighting Report - India. Daily News HBCC UFO Research, Box 1091 Houston, British Columbia, Canada - VOJ 1ZO.

(http://www.ufoinfo.com/sightings/india/010410.shtml), accessed on copyright 1996 2012). 